Jurnal Kesmas Asclepius

Volume 2, Nomor 2, Desember 2020

e-ISSN: 2684-8287

p-ISSN: 2656-8926

DOI: https://doi.org/10.31539/jka.v2i2.1765

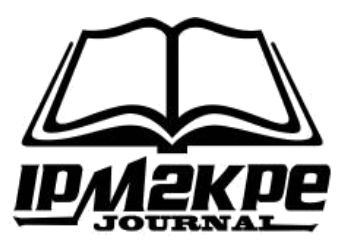

\title{
PENDIDIKAN DAN PARITAS TERHADAP PEMAKAIAN ALAT KONTRASEPSI BAWAH KULIT (AKBK)
}

\author{
Lia Hartini \\ Dinas Pengendalian Penduduk dan Keluarga Berencana \\ liahartini65@gmail.com
}

\begin{abstract}
ABSTRAK
Penelitian ini bertujuan untuk mengetahui hubungan antara pendidikan dan dan paritas dengan pemakaian Alat Kontrasepsi Bawah Kulit (AKBK) di Bidan Praktik Mandiri (BPM) Ermi Kelurahan Karya Bakti tahun 2020. Metode penelitian ini menggunakan metode survey analitik dengan pendekatan cross sectional. Hasil analisis univariat didapatkan dari 98 responden diketahui bahwa ibu yang menggunakan kontrasepsi AKBK sebanyak 35 orang $(35,7 \%)$ dan yang tidak menggunakan kontrasepsi AKBK sebanyak 63 orang $(64,3 \%)$. Sebagian besar ibu berpendidikan kurang yaitu sebanyak 64 orang $(65,3 \%)$, dan ibu yang berpendidikan baik yaitu sebanyak 34 orang $(34,7 \%)$. Dan sebagian besar ibu memiliki paritas rendah (mempunyai anak < 3)sebanyak 60 orang $(61,2 \%)$, dan ibu dengan paritas tinggi sebanyak 38,8\%. Berdasarkan hasil uji statistik chi square terhadap pendidikan didapatkan $\rho$ value 0,00 dan $\rho$ value terhadap paritas ibu 0,00. Simpulan, ada hubungan yang bermakna antara pendidikan dan paritas ibu terhadap pemakaian alat kontrasepsi bawah kulit.
\end{abstract}

Kata Kunci : Paritas, Pemakaian Alat Kontrasepsi Bawah Kulit (AKBK), Pendidikan

\section{ABSTRACT}

This study aims to determine the relationship between education and parity with the use of Under-the-Skin Contraceptives (AKBK) in Ermi's Independent Practice Midwives (BPM), Karya Bakti, 2020. This research method uses an analytical survey method with a cross sectional approach. The results of univariate analysis obtained from 98 respondents showed that there were 35 mothers (35.7\%) who used AKBK contraception and 63 people who did not use AKBK contraception (64.3\%). Most of the mothers with less education were as many as 64 people (65.3\%), and mothers with good education were 34 people (34.7\%). And most of the mothers had low parity (having children <3) as many as 60 people (61.2\%), and mothers with high parity were $38.8 \%$. Based on the results of the chi square statistical test on education, it was found that $\rho$ value was 0.00 and $\rho$ value on maternal parity was 0.00. In conclusion, there is a significant relationship between education and maternal parity on the use of contraceptives under the skin.

Keywords: Parity, Use of Under the Skin Contraceptives (AKBK), Education 


\section{PENDAHULUAN}

Keluarga berencana merupakan suatu usaha menjarangkan kehamilan atau merencanakan jumlah dan jarak kehamilan dengan menggunakan kontrasepsi. Sasaran utama program keluaraga berencana adalah Pasangan Usia Subur (PUS) yaitu pasangan yang wanitanya berusia antara 15-49 tahun, karena kelompok ini merupakan pasangan yang aktif melakukan hubungan seksual dan setiap kegiatan seksual dapat mengakibatkan kehamilan. Pasangan usia subur diharapkaan secara bertahap menjadi peserta KB yang aktif lestari sehingga memberi efek langsung penurunan fertilisasi (Suratun, 2015).

Implant atau alat kontrasepsi bawah kulit (AKBK) merupakan salah satu jenis alat kontrasepsi hormonal dan termasuk alat kontrasepsi jangka panjang yang efektif dalam upaya menjarangkan kehamilan. Keuntungan implant yakni memberikan perlindungan jangka panjang (sampai 5 tahun) aman karena tidak mempengaruhi kualitas dan kuantitas ASI dan kesuburannya cepat kembali setelah implant dilepas (Mulyani \& Rinawati, 2013; Laput, 2020).

Alat Kontrasepsi Bawah Kulit (AKBK) merupakan metode kontrasepsi hormonal yang memiliki efektivitas sangat tinggi serta memiliki angka kegagalan yang rendah yang sangat sesuai bagi pasangan usia subur yang ingin memakai kontrasepsi dalam jangka panjang untuk mengatur jarak kehamilan. Namun pada kenyataannya meskipun efektifitasnya tinggi peminatnya sangat sedikit (Sulistyawati, 2012; Tampubolon \& Tarigan, 2018).

Profil Kesahatan Indonesia tahun 2013 mencatat jumlah peserta KB aktif yang paling banyak menggunakan kontrasepsi dengan metode suntik sebesar $(46,87 \%)$, kemudian metode pil sebesar $(26,60 \%)$, metode IUD sebesar $(7,75 \%)$, metode MOP $(0,25 \%)$, metode MOW sebesar $(1,52 \%)$, metode Alat Kontrasepsi Bawah Kulit (AKBK) sebesar (9,23\%) dan metode kondom sebesar (6,09\%) (Kemenkes RI, 2018).

Tahun 2019 merupakan tahun terakhir dari Rencana Pembangunan Jangka Menegah Nasional (RPJMN) dan Rencana Strategi (Renstra) BKKBN 2015-2019. Sasaran Badan Kependudukan Dan Keluarga Berencana Nasional (BKKBN) ialah : 1). Menurunnya angka kelahiran total (Total FertilityRate/TFR) menjadi 2,28 per wanita, 2). Meningkatnya prevalensi kontrasepsi (Contraceptive Prevalensi Rate / CPR) sebesar $61,3 \%, 3$ ). Menurunnya kebutuhan ber KB yang tidak terpenuhi (unmetneed) sebesar 9,91\%,4). Meningkatnya peserta KB aktif yang menggunakan metode kontrasepsi jangka panjang (MKJP) sebesar 23,50 serta meningkatnya tingkat putus pakai kontrasepsi sebesar 24,6 \% (BKKBN, 2020).

Penelitian yang dilakukan oleh Ayu (2013) menunjukkan bahwa dari 68 responden yang berpengetahuan kurang adalah 25 orang dan yang berpengetahuan cukup adalah 21 orang dan selebihnya berpengetahuan baik. Kesimpulan penelitian ini membuktikan bahwa pengetahuan ibu usia subur memiliki hubungan dengan penggunaan alat kontrasepsi bawah kulit.

Berdasarkan penelitian yang dilakukan Yulviana (2017) menunjukan bahwa ibu yang tidak mendapatkan dukungan suami lebih berisiko 2,2 kali untuk tidak menggunakan AKBK dibandingkan ibu yang mendapatkan dukungan suami dalam penggunaan AKBK (C.I 95\% : 1,267-3,662).

Pemakaian kontrasepsi implant dipengaruhi oleh banyak faktor. Penelitian tentang faktor yang berhubungan dengan pemakaian kontrasepsi yang dilakukan di Ethiopia didapatkan bahwa pengetahuan dan paritas lebih dari dua mempunyai hubungan yang signifikan terhadap pemakaian alat kontrasepsi (Alemayehu et al., 
2012). Hal ini juga sependapat dengan penelitian yang dilakukan di Tanzania yang menyatakan bahwa pengetahuan, agama, penghasilan, hubungan sosial, daerah perkotaan, komunikasi antara pasangan dan informasi dari petugas kesehatan mempunyai hubungan yang signifikan terhadap pemakaian kontrasepsi (Mosha \& Ruben, 2013).

Dari data tersebut terlihat bahwa mayoritas jenis kontrasepsi yang digunakan atau dipilih oleh masyarakat adalah kontrasepsi oral, suntik dan implant bila dibandingkan dengan Alat Kontrasepsi Dalam Rahim (AKDR). Alat kontrasepsi bawah kulit merupakan salah satu metode kontrasepsi yang efektif terpilih, karena efektif dalam memberikan perlindungan terhadap terjadinya kehamilan, biaya pemasangan yang relatif cukup murah dengan masa pakai yang cukup lama dengan masa pakai hingga 3 tahun, kesuburan akan segera kembali setelah penghentian penggunaan metode ini.

Terkait sasaran di atas, hasil capaian BKKBN cukup menggembirakan. Berdasarkan hasil SDKI 2017, Angka Kelahiran Total (TFR) turun dari 2,6 anak dari SDKI 2012 menjadi 2,4 anak per wanita. Angka Kelahiran Menurut kelompok Umur (ASFR) 15-19 mengalami penurunan dari 48 (SDKI 2012) menjadi 36 pada SDKI 2017. Pemakaian kontrasepsi semua cara juga mengalami peningkatan dari $62 \%$ (SDKI 2012) menjadi $64 \%$ (SDKI 2017). Persentase kebutuhan ber KB yang tidak terpenuhi (unmetneed) mengalami penurunan dari 11,4 pada SDKI 2012 menjadi 10,6 \% pada SDKI 2017.

Ibu-ibu yang pernah melahirkan tiga kali atau lebih cenderung untuk membatasi dan mengatur jarak kelahiran dengan metode kontrasepsi yang paling aman, praktis dan mudah dijangkau seperti alat kontrasepsi bawah kulit (BPS, 2013).

\section{METODE PENELITIAN}

Desain penelitian yang dilakukan menggunakan metode survey analitik. Di dalam penelitian survey analitik, dari analisis korelasi dapat diketahui seberapa jauh kontribusi faktor resiko tertentu terhadap adanya kejadian tertentu (efek).

Populasi dalam penelitian ini adalah semua ibu yang datang untuk menggunakan alat kontrasepsi di Praktek Bidan Mandiri Ermi Kelurahan Karya Bakti Tahun 2020 dari bulan Juli-September 2020 yang tercatat dalam medical record yang berjumlah 127 orang.

Sedangkan sampel penelitian adalah sebagian yang diambil dari keseluruhan objek yang diteliti dan dianggap mewakili seluruh populasi ini. Pengambilan sampel secara random sampling (simple random sampling) yaitu pemilihan sampel yang memungkinkan tiap subjek dalam populasi mendapat kemungkinan yang sama untuk terpilih. Dimana teknik pengambilan sampel akan dilakukan menggunakan interval, dimana teknik ini merupakan modifikasi dari sampel random sampling. Caranya adalah membagi jumlah atau anggota populasi dengan perkiraan jumlah sampel yang diinginkan.

Adapun teknik analis data yang digunakan adalah analisis univariat dan analisis bivariat. Pada penelitian ini analisis univariat dilakukan pada variabel independent (pendidikan dan paritas) dan variabel dependen (alat kontrasepsi bawah kulit). Sedangkan analisis bivariat dilakukan terhadap dua variabel yang diduga berhubungan atau korelasi. Analisis bivariat bertujuan untuk melihat hubungan antara variabel independen yaitu pendidikan dan paritas dengan variabel dependen yaitu (Penggunaan alat kontrasepsi bawah kulit) yang dianalisis dengan uji statistik Chi-Square $\left(\mathrm{X}^{2}\right)$ dengan 
derajat kemaknaan $\alpha=0,05$ dan CI 95\%. Bila $\rho$ (value) $>\alpha$ berarti ada hubungan yang bermakna antara variabel independen dan variabel dependen.

\section{HASIL PENELITIAN}

Tabel.1

Distribusi Frekuensi

Pemakaian AKBK

\begin{tabular}{llcc}
\hline & & Frequency & Percent \\
\hline Pemakaian AKBK & Ya & 35 & 35,7 \\
& Tidak & 63 & 64,3 \\
& Total & 98 & 100.0 \\
\hline
\end{tabular}

Berdasarkan tabel 1 dapat diketahui bahwa ibu yang menggunakan kontrasepsi AKBK sebagian besar tidak menggunakan kontrasepsi AKBK yaitu sebanyak 63 orang $(64,3 \%)$.

Tabel. 2

Distribusi Frekuensi Responden berdasarkan Pendidikan

\begin{tabular}{llcc}
\hline & & Frequency & Percent \\
\hline Pendidikan & Baik & 34 & 34,7 \\
& Kurang & 64 & 65,3 \\
& Total & 98 & 100.0 \\
\hline
\end{tabular}

Berdasarkan tabel 2 dapat diketahui bahwa sebagian besar ibu berpendidikan kurang yaitu sebanyak 64 orang $(65,3 \%)$.

Tabel.3

Distribusi Frekuensi Responden

Berdasarkan Paritas

\begin{tabular}{llcc}
\hline & & Frequency & Percent \\
\hline Paritas & Tinggi & 38 & 38.8 \\
& Rendah & 60 & 61,2 \\
& Total & 98 & 100.0 \\
\hline
\end{tabular}

Berdasarkan tabel 3 dapat diketahui bahwa sebagian besar ibu memiliki paritas rendah (mempunyai anak <3) sebanyak 60 orang $(61,2 \%)$.

Tabel. 4

Hubungan Antara Pendidikan Ibu dengan Pemakaian AKDBK

\begin{tabular}{|c|c|c|c|c|c|c|c|c|}
\hline \multirow{3}{*}{ Pendidikan } & \multicolumn{4}{|c|}{ Pemakaian AKDR } & \multirow{2}{*}{\multicolumn{2}{|c|}{ Total }} & \multirow{3}{*}{$P$ Value } & \multirow{3}{*}{$\begin{array}{c}\text { OR } \\
(\mathrm{C} 195 \%)\end{array}$} \\
\hline & \multicolumn{2}{|c|}{$\mathrm{Ya}$} & \multicolumn{2}{|c|}{ Tidak } & & & & \\
\hline & $\mathrm{N}$ & $\%$ & $\mathrm{~N}$ & $\%$ & $\mathrm{~N}$ & $\%$ & & \\
\hline Baik & 30 & 88,2 & 4 & 11,8 & 34 & 100 & \multirow{2}{*}{0.00} & \multirow{2}{*}{$88(22-354)$} \\
\hline Kurang & 5 & 7,8 & 59 & 92,2 & 64 & 100 & & \\
\hline Jumlah & 35 & 96,0 & 63 & 104 & 98 & 100 & & \\
\hline
\end{tabular}


Berdasarkan table 4 menunjukkan bahwa kelompok ibu yang berpendidikan baik dengan frekuensi memakai alat kontrasepsi bawah kulit berjumlah 30 orang $(88,2 \%)$ lebih besar dibandingkan dengan ibu yang berpendidikan kurang dengan memakai alat kontrasepsi bawah kulit sebanyak 5 orang $(7,8)$.

Sedangkan ibu dengan kelompok pendidikan baik dengan tidak menggunakan alat kontrasepsi bawah kulit berjumlah 4 orang $(11,8 \%)$ lebih kecil dibandingkan dengan kelompok ibu yang pendidikan kurang dan tidak menggunakan alat kontrasepsi bawah kulit berjumlah 59 (92,2\%). Hasil uji statistik didapatkan nilai $\rho=0,000(\alpha=0,05)$, berarti ada hubungan bermakna antara pendidikan dengan pemakaian alat kontrasepsi bawah kulit.

Tabel. 5

Hubungan antara Paritas Ibu Hamil dengan Pemakaian AKBK

\begin{tabular}{|c|c|c|c|c|c|c|c|c|}
\hline \multirow{3}{*}{ Paritas } & \multicolumn{4}{|c|}{$\begin{array}{c}\text { Pemakaian Alat Kontrasepsi } \\
\text { Bawah Kulit } \\
\end{array}$} & \multirow{2}{*}{\multicolumn{2}{|c|}{ Total }} & \multirow{3}{*}{$\mathrm{P}$} & \multirow{3}{*}{$\begin{array}{c}\text { OR } \\
(\mathrm{C} 195 \%)\end{array}$} \\
\hline & \multicolumn{2}{|c|}{$\mathrm{Ya}$} & \multicolumn{2}{|c|}{ Tidak } & & & & \\
\hline & $\mathrm{N}$ & $\%$ & $\mathrm{~N}$ & $\%$ & $\mathrm{~N}$ & $\%$ & & \\
\hline Tinggi & 34 & $89,5 \%$ & 4 & $10,5 \%$ & 38 & 100 & \multirow{3}{*}{0,000} & \multirow{3}{*}{$5(53,8-4671)$} \\
\hline Rendah & 1 & $1,7 \%$ & 59 & $98,3 \%$ & 60 & 100 & & \\
\hline Jumlah & 35 & & 63 & & 98 & & & \\
\hline
\end{tabular}

Berdasarkan tabel 5 menunjukkan bahwa kelompok ibu yang berparitas tinggi yang memakai alat kontrasepsi bawah kulit berjumlah 34 orang $(89,5 \%)$ lebih besar dibandingkan dengan proporsi ibu berparitas tinggi dengan tidak memakai alat kontrasepsi bawah kulit yang hanya berjumlah 4 orang $(10,5 \%)$. Hasil analisis uji statistik menunjukkan bahwa nilai p-0,000 artimya ada hubungan antara paritas ibu hamil dengan pemakaian AKBK.

\section{PEMBAHASAN}

Berdasarkan hasil analisa data uji statistik $\left(\mathrm{X}^{2}\right)$ dapat dikatakan bahwa kelompok ibu yang berpendidikan baik dengan frekuensi memakai alat kontrasepsi bawah kulit berjumlah 30 orang $(88,2 \%)$ lebih besar dibandingkan dengan ibu yang berpendidikan kurang dengan memakai alat kontrasepsi bawah kulit sebanyak 5 orang $(7,8)$.

Lebih jauh dilihat berdasarkan hasil uji statistik ada hubungan bermakna antara pendidikan dengan pemakaian alat kontrasepsi bawah kulit. Dilihat dari OR $=88$ artinya ada hubungan yang bermakna antara pendidikan ibu hamil dengan pemakaian alat kontrasepsi bawah kulit dan ibu pada kelompok berpendidikan tinggi peluang untuk memakai alat kontrasepsi bawah kulit sebesar 88 kali lipat dibandingkan dengan ibu pada kelompok berpendidikan rendah.

Hasil penelitian ini sejalan dengan penelitian Lontaan \& Kusmiyati (2014) yang menyatakan ada hubungan antara pendidikan dengan pemilihan kontrasepsi pada PUS, dari pendidikan menunjukkan bahwa responden tingkat pendidikan tinggi (11\%) lebih banyak memilih metode kontrasepsi jangka panjang dibandingkan dengan responden tingkat pendidikan dasar $(7 \%)$. Hasil analisis statistik $\rho=0.000(\rho<0,05)$ artinya ada hubungan antara tingkat pendidikan dengan pemilihan kontrasepsi. 
Hasil penelitian hubungan pendidikan dan paritas terhadap pemakaian Alat Kontrasepsi Bawah Kulit (AKBK) di BPM Ermi Kelurahan Karya Bakti tahun 2020 data ini diperoleh dengan mengundi sebanyak 127 responden sampai berjumlah 98 responden. Dari hasil penelitian ini menunjukkan bahwa ibu yang berpendidikan kurang sebanyak 64 orang $(65,3 \%)$, ibu yang berpendidikan baik yaitu sebanyak 34 orang $(34,7 \%)$.

Dari hasil uji statistik, didapatkan ada hubungan yang bermakna antara paritas ibu pemakaian alat kontrasepsi bawah kulit dan ibu pada kelompok paritas tinggi peluang untuk memakai alat kontrasepsi bawah kulit sebesar 5 kali lipat dibandingkan ibu yang berparitas rendah.

Hal ini sejalan dengan hasil survey yang dilakukan pada ibu-ibu yang pernah melahirkan tiga kali atau lebih cenderung untuk membatasi dan mengatur jarak kelahiran dengan metode kontrasepsi yang paling aman, praktis dan mudah dijangkau seperti alat kontasepsi bawah kulit.

Paritas ibu yang tinggi (anak $\geq 3$ ) memberikan peluang yang lebih besar untuk memakai alat kontrasepsi bawah kulit mungkin dikarenakan jumlah anak yang sudah banyak sehingga mendorong ibu untuk memilih alat kontrasepsi aman, memiliki efektifitas tinggi dan memiliki jangka efektifitas yang lama seperti alat kontrasepsi bawah kulit.

Menurut penelitian Neri et al., (2017) efek kontrasepsi yang sangat baik dengan keamanan dan akseptabilitas, terutama dalam hubungan dengan pemeliharaan kualitas hidup yang baik, seksualitas dan penurunan desminore. Keluarga Berencana (KB) merupakan salah satu program pelayanan kesehatan preventif paling berperan dalam pengendalian pertumbuhan jumlah penduduk sehingga dapat meningkatkan kesehatan dan kesejahteraan bagi keluarga (Prastika et al., 2019).

Berbeda dengan penelitian yang dilakukan Laput (2020) yang menyatakan bahwa tidak terdapat pengaruh antara paritas terhadap penggunaan kontrasepsi implant di wilayah kerja Puskesmas Wae Mbeleng, Kecamatan Ruteng. Selanjutnya Laput (2020) menyatakan bahwa jumlah anak hidup mempengaruhi pasangan usia subur dalam menentukan metode kontrasepsi yang akan digunakan. Pada pasangan dengan jumlah anak hidup masih sedikit terdapat kecenderungan untuk menggunakan metode kontrasepsi dengan efektivitas rendah, sedangkan pada pasangan dengan jumlah anak hidup banyak terdapat kecenderungan menggunakan metode kontrasepsi dengan efektivitas yang lebih tinggi.

\section{SIMPULAN}

Adanya hubungan yang bermakna antara pendidikan dengan pemakaian alat kontrasepsi bawah kulit (AKBK). Adanya hubungan yang bermakna antara paritas ibu dengan pemakaian alat kontrasepsi bawah kulit (AKBK).

\section{SARAN}

Saran dari penelitian ini diharapkan petugas kesehatan khususnya bidan diharapkan dapat mengadakan upaya untuk meningkatkan konseling kepada masyarakata khususnya pada ibu dengan pasangan usia subur mengenai manfaat dan keuntungan memakai alat kontrasepsi bawah kulit, agar tingkat pengetahuan dan sikap ibu mengenai alat kontrasepsi bawah kulit menjadi meningkat. 
Selain itu diharapkan dapat mengup-date dan menambah sumber kepustakaan tentang buku-buku, majalah mengenai keluarga berencana dan jurnal kesehatan dan penelitian terdahulu yang berkaitan dengan metodologi penelitian dan biostatistik yang dapat digunakan untuk melengkapi referensi kepustakaan sehingga dapat menambah sumber penelitian bagi penelitian selanjutnya, serta dapat memberikan informasi dan pengetahuan bagi peneliti yang akan datang dalam meneliti variabel lainnya seperti pendidikan, akses informasi, serta keterbatasan pilihan metode kontrasepsi dan sarana pelayanan yang berhubungan dengan pemakaian kontrasepsi AKBK dengan menggunakan metode-metode penelitian yang berbeda sehingga penelitian mengenai AKBK dapat terus dikembangkan.

\section{DAFTAR PUSTAKA}

Alemayehu, M., Belachew, T., \& Tilahun, T. (2012). Factors Associated with Utilization of Long Acting and Permanent Contraceptive Methods among Married Women of Reproductive Age in Mekelle Town, Tigray Region, North Ethiopia. BMC Pregnancy and Childbirth, 12(1), 6. DOI:10.1186/1471-2393-12-6

Ayu, A. (2013). Hubungan Pengetahuan Ibu Usia Subur tentang Alat Kontrasepsi Bawah Kulit dengan Tingkat Penggunaan Alat Kontrasepsi Bawah Kulit di Klinik Rehulina Br Sitepu Desa Bandar Khalifah pada Tahun 2013

Badan Pusat Statisktik (BPS). (2013). Presentasi Pemakaian Alat Kontrasepsi Provinsi BKKBN. (2020). SDKI Capaian Penggunaan Kontrasepsi 2017

Kementrian Kesehatan RI. (2018). Profil Kesehatan Indonesia. Jakarta: Kemenkes RI Laput, D. O. (2020). Pengaruh Paritas terhadap Penggunaan Kontrasepsi Implant di Wilayah Kerja Puskesmas Wae Mbeleng, Kecamatan Ruteng. Jurnal Wawasan Kesehatan, 5(1), 6-10

Lontaan, A., \& Kusmiyati, K. (2014). Faktor-Faktor yang Berhubungan dengan Pemilihan Kontrasepsi Pasangan Usia Subur di Puskesmas Damau Kabupaten Talaud. Jurnal Ilmiah Bidan, 2(1), 27-32. https://doi.org/10.47718/jib.v2i1.312

Mosha, I. H., \& Ruben, R. (2013). Communication, Knowledge, Social Network and Family Planning Utilization among Couples in Mwanza, Tanzania African. Journal of Reproductive Health, 17(3), 57-69. https://www.jstor.org/stable/23485713

Mulyani, S. N., \& Rinawati, M. (2013). Keluarga Berencana dan Alat Kontrasepsi. Yogyakarta: Nuha Medika

Neri, M., Piras, B., Paoletti, A. M., Vallerino, V., Corda, V., Ronchetti, C., Taccori, V., Pilloni, M., Zedda, P., Capobianco, G., Dessole, S., Melis, G. B., \& Mais, V. (2017). Long-Acting Reversible Contraception (LARC) with the Intrauterine System with Levonorgestrel $(6 \mathrm{Mcg} / \mathrm{D})$ : Observational Study on the Acceptability, Quality of Life, and Sexuality in Italian Women. Gynecological Endocrinology, 34(6),532-535. https://doi.org/10.1080/09513590.2017.1416465

Prastika, B. P.S., Armini, N. K. A., \& Pradanie, R. (2019). Hubungan Dukungan Suami dan Gaya Hidup dengan Kualitas Hidup Akseptor KB IUD di Wilayah Kerja Puskesmas Mulyorejo Surabaya. Universitas Airlangga

Sulistyawati, A. (2012). Pelayanan Keluarga Berencana. Yogyakarta

Suratun, S. (2015). Pelayanan Keluarga Berencana. Jakarta: Cv. Trans Info Media 
Tampubolon, I. L., \& Tarigan, J. (2018). Hubungan Pengetahuan, Dukungan Suami dan Petugas Kesehatan dengan Penggunaan Alat Kontrasepsi Bawah Kulit (AKBK) pada Pasangan Usia Subur dii Lingkungan II Kelurahan Nelayan Indah Kecamatan Medan Labuhan. Jurnal Bidan Komunitas, 1(2), 59-66. http://ejournal.helvetia.ac.id/index.php/jbk

Yulviana, R. (2017). Faktor-Faktor yang Berhubungan dengan Penggunaan Alat Kontrasepsi Bawah Kulit di Kecamatan Payung Sekaki Kota Pekanbaru Tahun 2015 . Menara Ilmu, $11(75)$ 149-154. https://jurnal.umsb.ac.id/index.php/menarailmu/article/view/158 